This document is the accepted manuscript version of the following article:

King, G., Fonti, P., Nievergelt, D., Büntgen, U., \& Frank, D. (2013). Climatic drivers of hourly to yearly tree radius variations along a $6^{\circ} \mathrm{C}$ natural warming gradient. Agricultural and Forest

Meteorology, 168, 36-46. https://doi.org/10.1016/j.agrformet.2012.08.002

This manuscript version is made available under the CC-BY-NC-ND 4.0

1icense http://creativecommons.org/1icenses/by-nc-nd/4.0/

\title{
a $6^{\circ} \mathrm{C}$ natural warming gradient
}

3

4

$$
\text { Greg King }{ }^{1,2 *} \text {, Patrick Fonti }{ }^{1} \text {, Daniel Nievergelt }{ }^{1} \text {, Ulf Büntgen }{ }^{1,2} \text {, David Frank }{ }^{1,2}
$$

5

${ }^{1}$ Swiss Federal Research Institute WSL, Zürcherstrasse 111, 8903 Birmensdorf, Switzerland

${ }^{2}$ Oeschger Centre for Climate Change Research, Zähringerstrasse 25, 3012 Bern, Switzerland

*Corresponding author: e-mail: gregory.king@wsl.ch; phone: +41. (0)44.739.2816

Additional author e-mails: 
Abstract

Climate influences the timing, rate and dynamics of tree growth from sub-hourly to multicentennial timescales. Monitoring of stem radius variations on the temporal scales at which many physiological processes operate is necessary to obtain insight into intra-annual stem dynamics and contribute to the understanding of climate impacts on growth processes. Here, we quantify the response of radial conifer stem size to environmental fluctuations via a novel assessment of tree circadian cycles from four years of sub-hourly data collected from 56 larch and spruce trees growing along a natural temperature gradient of $\sim 6^{\circ} \mathrm{C}$ located in the central Swiss Alps. During the growing season tree stem diameters were greatest at mid-morning and smallest in the late evening, reflecting the balance of transpiratory water loss and uptake from the roots. Along the gradient, amplitudes calculated from the stem radius cycle were $\sim 50 \%$ smaller at the upper site $(\sim 2200 \mathrm{~m}$ a.s.1.) relative to the lower site $(\sim 800$ $\mathrm{m}$ a.s.1.). We show that typical growing season diurnal cycles are substantially modified by changes in precipitation, temperature and cloudiness; amplitudes were nine times smaller on days with rain $(>10$ $\mathrm{mm}$ ) and daily amplitudes increase by $\sim 40 \%$ if mean daily temperature is between $15-20^{\circ} \mathrm{C}$ compared to $5-10^{\circ} \mathrm{C}$. We find that over the growing season in the sub-alpine forests, spruce show greater daily stem water movement than larch. However, under projected future warming, larch could experience up to $50 \%$ greater stem water-use, which on already dry sites may severely affect future growth. Our data further indicate that the confounding influences of radial growth and short-term water dynamics on stem size likely lead to an overstated importance of water-linked meteorological variables on intraannual tree growth using conventional methodology. We suggest that intra-seasonal measurements of cellular development and consideration of reversible changes in stem diameter due to climatic factors will be necessary to reduce possible biases in quantifying and attributing changes in forest productivity in response to future warming. 
Keywords:

dendrochronology; dendrometer; altitudinal gradient; diurnal cycles; Larix decidua; Picea abies

\section{Introduction}

Trees play a key role in the dynamics and coupling of the carbon and hydrological cycles

(Hutjes et al., 1998; Prentice et al., 2000). In forested regions, approximately half of the precipitation is returned to the atmosphere through tree stems (Oki and Kanae, 2006). In parallel, tree photosynthetic activity constitutes approximately $50 \%$ of the total terrestrial net primary production (Bonan, 2008).

These characteristics, together with additional ecosystem services, make the quantification of tree growth and its environmental interactions an important task, especially under continuing global change (IPCC, 2007).

Atmosphere-landscape feedbacks are an example of important regional to global phenomena well addressed by large-scale data sets and modelling approaches (Seneviratne et al., 2006; Frank et al., 2010; Jung et al., 2010), although tree-based measurements are still necessary to monitor and attribute growth. Repeated observations (e.g., tree diameter and height) are commonly employed to track biomass accumulation (Husch et al., 2003), whereas increment cores provide retrospective quantification of annual radial growth (Fritts, 1976). These methods offer the basis to statistically link inter-annual to long-term growth with, at best, monthly climatic variables. To improve our understanding of the physiological mechanisms driving tree growth, sub-daily and cellular scale data are required.

Dendrometers meet these conditions by recording stem radius at sub-hourly and micrometer

60 resolution (Daubenmire, 1945; Bormann and Kozlowski, 1962; Drew and Downes, 2009), with

61 observed variations representing a combination of growth together with water transport and storage 
62 (Herzog et al., 1995; Zweifel and Häsler, 2001). Automatic dendrometers are now widely used to

63 provide data on coniferous and broadleaf trees from boreal to tropical forests (Perez et al., 2009; Biondi

64 and Hartsough, 2010; Nabeshima et al., 2010; Oberhuber and Gruber, 2010; Duchesne and Houle,

65 2011). For example, dendrometers have been used to quantify and date the seasonal progress of wood

66 formation, providing the basis for intra-annual tracing of isotope (e.g. $\delta^{13} \mathrm{C}$ and $\delta^{18} \mathrm{O}$ ) signatures from

67 source to sink for an entire growing season (Gessler et al., 2009; Offermann et al., 2011). However,

68 most studies have focused on isolating tree growth, typically via the so-called "daily" (Tardif et al.,

69 2001; Bouriaud et al., 2005), or "stem cycle" (Downes et al., 1999; Deslauriers et al., 2003)

70 approaches, to explore the influence of environmental variables. Over three years Deslauriers et al.

71 (2003) attributed daily radial growth of balsam fir (Abies balsamea (L.) Mill.) in the boreal forest

72 primarily to water availability and demands. Similarly, daily radial changes of tree species from

73 Ecuador and Ethiopia measured with dendrometers were explained by available moisture with the

74 vapour pressure deficit and precipitation being the most important factors (Bräuning et al., 2009;

75 Krepkowski et al., 2011). The daily increment of Pinus cembra (L.) at the alpine ecotone (Gruber et al.,

76 2009) has also been positively correlated with changes in tree water status (relative humidity and

77 precipitation). Less emphasis has been placed on the stem water signal and how it actually may

78 confound the attribution of growth (Zweifel et al., 2001; Makinen et al., 2003). Consequently,

79 investigations focusing on tree water balance will contribute to improving the isolation of the growth

80 signal, quantifying processes such as transpiration rates and water-use efficiency, and increasing

81 understanding of soil-plant-atmosphere coupling.

Here, we present high-resolution stem radius measurements collected over four years (20072010). We use a novel data analysis approach to i) isolate diurnal cycles, ii) examine the stem water signal and iii) attribute the influence of environmental drivers. These analyses are examined in two 
85 different common alpine species: Norway spruce (Picea abies Karst.) and European larch (Larix

86 decidua Mill.), along a temperature gradient over a complete year. To this end, sub-hourly stem radius

87 measurements from 56 trees at eight sites along a $1400 \mathrm{~m}$ altitudinal gradient were collected with

88 associated instrumental data. The altitudinal transects provide a $\sim 6^{\circ} \mathrm{C}$ growing season temperature

89 difference, roughly corresponding to the projected increase of Switzerland summer temperatures to the

90 year 2100 under scenario A1B $(\mathrm{CH} 2011,2011)$ and allowing us to make inferences as to the impacts of

91 a warming climate. 
Our study was conducted across two altitudinal transects centered in the Lötschental

$95\left(46^{\circ} 23^{\prime} 40^{\prime \prime} \mathrm{N}, 7^{\circ} 45^{\prime} 35^{\prime \prime} \mathrm{E}\right)$, an inner-alpine valley located in the central Swiss Alps (Fig. 1a). The valley is enclosed by steep forested slopes (mostly $>60 \%$ ) primarily composed of mixed, evergreen Norway spruce and deciduous European larch extending to $\sim 2300 \mathrm{~m}$ a.s.l. The soils along the transect are acidic and characterized by a large stone content and low amounts of clay. Different soil types were observed, ranging from Leptosol, Cambisol to Podzol, with intermediates (IUSS Working Group WRB, 2006). The soils were formed from calcareous-free parent material, including moraines and crystalline bedrock (gneiss and granite) from the Aar massif (Jemelin et al.,

102 1985). The region has a cool climate with a mean annual temperature of $5.7^{\circ} \mathrm{C}$, ranging from $-3.3^{\circ} \mathrm{C}$ 103 (January) to $14.8^{\circ} \mathrm{C}$ (July). As a relatively dry region, the mean annual precipitation is $825 \mathrm{~mm}$ and

104 is well distributed throughout the year with precipitation falling predominantly as snow between

105 November and March (MeteoSwiss sites, Fig. 1a). During the study (2007-2010) conditions were

106 broadly similar to the long-term average (1987-2006) except for a slightly warmer spring

107 (attributable to a very warm 2007) and more precipitation received over the late spring and summer 108 and less in the early autumn (Fig. 2).

Measurements were performed at eight sites (Fig. 1). Seven sites were established at $300 \mathrm{~m}$

110 elevation intervals starting from the valley bottom, located at $\sim 1300 \mathrm{~m}$ a.s.1., along both the

111 northwest and southeast slope aspects until $2200 \mathrm{~m}$ a.s.1., just below the upper forest limit. To

112 further extend the altitudinal gradient, an additional site was established in early 2008 just outside

113 of the Lötschental in the main Rhône valley on a north-facing slope at an elevation of $\sim 800 \mathrm{~m}$ a.s.l.

114 Codes for aspect and altitude (in hundreds of meters) were assigned to each site (e.g. N13 or S22).

115 Site temperatures decline by $0.47^{\circ} \mathrm{C} / 100 \mathrm{~m}$ on the south- and $0.42{ }^{\circ} \mathrm{C} / 100 \mathrm{~m}$ on the north-facing 116 slope and between-slope differences were generally absent. 


\subsubsection{Dendrometers}

119 At each site, with the exception of N22 and S22 which are above the local altitudinal range

120 of spruce, four mature, dominant and healthy trees of each species (Picea abies and Larix decidua)

121 were selected for a total of 56 trees. The sampled trees have average heights of $27 \mathrm{~m}$ and diameters

122 of $44 \mathrm{~cm}$, and were similar for both species. Trees located along the two transects are generally

123 older at higher elevations (e.g., average of 251 years at $2200 \mathrm{~m}$ a.s.1. and 116 at N13), with larch

124 and spruce exhibiting similar ages at the same site (Bechet, 2010). Automatic dendrometers were

125 installed on all trees to continuously measure stem radius changes (DR, $\underline{D}$ ifference in $\underline{R}$ adius over

126 time). Two different dendrometer types were equally distributed among species and sites: a point

127 dendrometer and a circumference dendrometer, models DR and DC-1, respectively (Ecomatik,

128 Munich, Germany). The measurement of stem radius requires the conversion of a distance change

129 in the sensor rod for the point dendrometers (band length for the circumference dendrometers) into

130 an electrical signal using a linear variable differential transformer. Signals were corrected for

131 thermal sensitivity according to the manufacturer's specifications.

132 Data were recorded from October 2006 to October 2010 with a sampling resolution of

133 hourly or better. The resulting data were processed to identify and correct errors due to factors such

134 as animals eating wires, moisture entering the data logger housing, fallen trees, and on one occasion

135 an errant (or precisely placed) hunting bullet. In addition, tension on the dendrometer sensor rods

136 and wire bands was periodically adjusted to remain within the manufacturer's measurement range

137 as the trees grew. Gaps (which remained unfilled) and abrupt jumps were corrected considering

138 series from neighboring trees without the corresponding inhomogeneity. Sub-hourly DR values

139 were averaged to hourly resolution. To investigate diurnal cycles, the overall growth trend was

140 removed from the data by calculating daily means for each sensor and subtracting it from the 141 measurements. 


\subsubsection{Meteorological Measurements}

144 Site conditions were continuously monitored using a variety of sensors. From 2006 onwards

145 stem temperatures at each site were measured every 15 minutes with a temperature logger (Onset,

146 Tidbit) installed on a single tree at about $1.6 \mathrm{~m}$ above the ground and protected from direct solar

147 radiation. Starting in the spring of 2008, air temperature, relative humidity $(\mathrm{RH})$ and dew point

148 were recorded at $15 \mathrm{~min}$ resolution using a sensor (Onset, U23 Pro) placed beneath the canopy at

149 each site. Furthermore, temperature, precipitation and radiation records were compiled using a

150 network of MeteoSwiss sites in the region (Fig. 1a). This network was selected based on multiple

151 comparisons including those with a temporary meteorological station installed in the Lötschental

152 near the village of Wiler. This network provided a historical baseline (1987-2006) of hourly

153 precipitation and temperature observations for our study.

\subsection{Data Analysis}

To explore the characteristic diurnal cycle of DR, which resembles a sinusoid waveform, we

157 define several metrics based on characteristic data patterns (Fig. 3). The local maximum ( $\left.\mathrm{R}_{\max }\right)$ and

158 minimum $\left(\mathrm{R}_{\min }\right)$ are found at the critical points of the wave. From these points, the timing of the

159 daily maximum $\left(\mathrm{T}_{\max }\right)$ and minimum $\left(\mathrm{T}_{\min }\right)$ were calculated, as well as the peak-to-peak amplitude

$160\left(\Delta \mathrm{R}=\mathrm{R}_{\max }-\mathrm{R}_{\min }\right)$. On rare days when stem size increased monotonically, no values were assigned.

161 To investigate the influence of air temperature on diurnal amplitude over the growing season

162 we averaged observations over all years and used site as our unit of replication $(\mathrm{n}=8)$. As we are

163 interested in a general response across all elevations, a linear mixed-effects model (R package

164 lme4) was fit to the data considering air temperature as a fixed effect and site as a random effect. To

165 compare species response we fit larch and spruce independent of each other. As there is no

166 consensus as to the best method for calculating an R2 for this type of regression, we instead 
167 calculate the correlation between observed and predicted values (Byrnes et al., 2006) for an

168 intuitive measure of how well our proposed model explains observed variation in the data.

169 To further explore circadian cycle shifts during the growing season, we classified and

170 averaged daily changes in stem size according to meteorological conditions as reported in the

171 regional network. We calculated different classes for daily precipitation, temperature, sunshine

172 percentage as well as a weather index combining precipitation and sunshine amounts. Each of these

173 variables was selected based upon previous research that identified their importance for tree

174 transpiration processes (Jarvis and McNaughton, 1986).

175 All analyses were performed using the R statistical environment (R Development Core

176 Team, 2012). 


\section{3. Results}

\subsection{Stem radius variations}

From 2007-2010, the stem radius variations (DR) showed annual and daily cycles

181 characteristic of trees growing in temperate regions (Fig. 4). Trees generally reveal a synchronous

182 response, although more coherence is found at the site-level than across the altitudinal transect. The

183 annual variability is characterized by a progressive increase of stem radius beginning in the spring,

184 a plateau in late summer and a decrease during the winter months (Fig. 4a and 4c). The stem radius

185 increase is closely linked with the main period of xylogenesis. The subsequent plateau in stem size

186 suggests a reduction in cellular division and expansion, while the winter decrease indicates stem

187 desiccation. At our sites, the amplitude of this seasonal cycle is in the range of several thousand

188 micrometers. Within these annual cycles we also observe more abrupt stem size variations in both

189 larch and spruce, usually on the order of hundreds of micrometers. Decreases during the wintertime

190 are related to freezing events, while increases during the growing season are associated with

191 precipitation. At higher resolution during the growing season (Fig. $4 \mathbf{b}$ and d), the DR variations

192 show a clear diurnal cycle that appears to be primarily elastic. Obscuration of this daily cycle by

193 stem expansion during precipitation events is readily visible. The daily amplitude during the

194 growing season is about $100 \mu \mathrm{m}(0.1 \mathrm{~mm})$. Figure 5 provides a close-up of the stem contraction

195 events from December 2009 and shows their relation to site-specific air temperatures below $-5^{\circ} \mathrm{C}$

196 (shaded in red). During this period, the "threshold" temperature is reached at all sites around

197 December 14 and remains low for between 5 and 7 days, with much colder temperatures, a longer

198 duration and larger stem contractions at higher elevations (e.g. S19 drops below $-15^{\circ} \mathrm{C}$ and has a

199 stem contraction of about $2000 \mu \mathrm{m}$ ). Stem size at N08 (the lowest elevation) recovers more quickly

200 and does not record the subsequent temperature decrease and corresponding stem contraction

201 around 28 December. 
Comparisons of monthly mean diurnal cycles over a full year reveal variation with the seasons and with site elevation (Fig. 5 and Table 1). The amplitude and phase of the cycles were

204 found to vary along the course of 12 months with notable differentiation between summer and

205 winter. The summer and winter patterns contain a local amplitude maximum in July $(99.8 \pm 31.4$

$206 \mu \mathrm{m})$ and February $(30.5 \pm 18.0 \mu \mathrm{m})$, respectively, with the amplitudes being much larger during the

207 summer than the winter. The summer and winter patterns are most characteristically differentiated

208 by a phase shift in the diurnal cycle. During the summer, a local maximum occurs between 0700

209 and 0900 Central European Time (CET; i.e., between the $8^{\text {th }}$ and $10^{\text {th }}$ hours of the day) followed by

210 a local minimum between 1700 and 2000 CET. Conversely, in the winter the maximum is found

211 between 1700 and 1900 CET, while the local minimum occurs between 0900 and 1100 CET. In

212 addition to the seasonal influence, the characteristics of the daily cycle also change along the

213 altitudinal gradient. As site elevation decreases from $2200 \mathrm{~m}$ (orange line) to $800 \mathrm{~m}$ (red line) a

214 parallel increase in amplitude is observed, consistent with the observation of the greatest amplitudes

215 during the warmest months. Similarly, as elevation increases, the phase shift in the diurnal cycles

216 from the winter to summer pattern takes place at a later date. These observations of the diurnal

217 amplitude and phase and their modulation with site elevation and the seasonal progression suggest

218 that these characteristics are driven by climatic controls and also provide insight about water

219 movement and storage in trees.

Air temperature is the primary environmental factor that changes with seasons and along the

221 gradient. To investigate its influence on daily cycle amplitudes we plotted monthly mean

222 amplitudes against mean monthly temperatures (April to October) for each site (Fig. 6). The linear

223 mixed effects model revealed a positively correlated increase in the amplitude of the diurnal cycle

224 with increased air temperatures for both species $\left(\right.$ Larch: $\mathrm{R}^{2} \mathrm{COR}=0.868$, d.f. $=56 ;$ Spruce: $\mathrm{R}^{2} \mathrm{COR}=$

2250.766 , d.f. $=40)$. Each species had very different intercept values $(55.88$ and $6.804 \mu \mathrm{m}$, for spruce

226 and larch respectively), indicating that within the current temperature range, spruce experience 
227 larger peak-to-peak amplitudes than larch (e.g. at a temperature of $10^{\circ} \mathrm{C}$, expected amplitude of 228 spruce is $118.4 \mu \mathrm{m}$, whereas larch is $94.4 \mu \mathrm{m}$ ). The slopes of the species regressions were also 229 different $(6.252 \mu \mathrm{m}$ for spruce and $6.804 \mu \mathrm{m}$ for larch), which under projected scenarios of 230 warming replicated by the altitudinal gradient would mean an approximate $48 \%$ increase in 231 amplitude for an average larch (compared to a 30\% increase for spruce) during the month of June.

\subsection{Climatic influence on diurnal stem cycles}

To obtain further insights as to the influence of climatic factors on the diurnal cycle during 235 the growing season (April-October), data were classified according to levels of precipitation, 236 temperature and sunshine (Fig.7 and Table 2). Amplitude of the daily cycle was inversely related

237 to precipitation amounts (Fig. 7a). During the growing season, days without precipitation reveal 238 mean amplitudes of $95.8 \pm 34.5 \mu \mathrm{m}$, compared to $10.6 \pm 4.5 \mu \mathrm{m}$ on days with $>10 \mathrm{~mm}$ of

239 precipitation. The time of the local maximum stem radius $\left(\mathrm{R}_{\max }\right)$ on these days was also delayed by 240 about two hours $(8.14 \pm 0.2$ to $10.25 \pm 0.3$ hours). Increases in stem radius over a full day were 241 generally observed starting with the $1-5 \mathrm{~mm}$ precipitation category, with a tendency toward 242 monotonic increases in stem size during larger precipitation events. Conversely, an increase in the 243 daily cycle amplitude is observed with a higher average daily temperature (Fig. 7b). Days with a 244 mean temperature from 5 to $10^{\circ} \mathrm{C}$ show daily amplitudes about $40 \%$ smaller than days with mean

245 temperatures between 15 and $20^{\circ} \mathrm{C}$. Despite days with higher temperature leading to general 246 decreases in stem radius, no monotonic decreases were observed. Similarly, a greater amount of 247 sunshine results in a greater amplitude of the diurnal cycle (Fig. 7c). On cloudy days $(0-20 \%$ 248 sunshine) the average amplitude is $11.4 \pm 8.6 \mu \mathrm{m}$, compared with sunny days ( $>60 \%$ sunshine) 249 when the average amplitude is $106.2 \pm 35.2 \mu \mathrm{m}$. Additionally, $\mathrm{T}_{\max }$ occurs about 4 hours earlier in 250 the day as the sunshine percentage increases from $0 \%$ to $>60 \%$. These amplitude increases suggest 
251 a depletion of stem water reserves in response to greater evaporative demand driven by warmer 252 temperatures and increased sunshine.

While the data show a clear response of diurnal cycles to climatic variables, attributing this

254 response is challenged by the correlation among parameters (e.g., sunny days also tend to be warm

255 days). To help address this, we calculated average daily cycles for a weather index grouping days

256 according to combined radiation (i.e., greater than or less than $40 \%$ sunshine) and presence of

257 precipitation (Fig. 7d). The amplitudes during sunny days are minimally affected by the presence

$258(104.6 \pm 30.8 \mu \mathrm{m})$ or absence $(100.0 \pm 33.8 \mu \mathrm{m})$ of rain. However, cloudy days (independent of

259 precipitation) have about 50\% lower amplitude than sunny days and large differences in amplitude

260 with $(28.9 \pm 14.2 \mu \mathrm{m})$ or without $(72.4 \pm 27.3 \mu \mathrm{m})$ precipitation. These patterns suggest that

261 radiation has a greater influence on the diurnal cycles than precipitation, whose influence is

262 moderated by the amount of radiation. These results support the observation that transient

263 atmospheric conditions are coupled with daily water movement within tree stems.

264 In addition to the responses due to short-term atmosphere-tree coupling, the diurnal cycle

265 characteristics can also supply information about plant responses to the more slowly changing soil

266 conditions. In the Lötschental, soil water reserves during the growing season are primarily

267 recharged by precipitation; we therefore investigate diurnal cycle modulation as a function of the

268 time since the last rain event (Fig. 8). As the length of the rain-free period increases, a clear

269 tendency for decreasing amplitude is observed in both species, although overall, spruce show a $40 \%$

270 greater average amplitude of the diurnal cycle $(96.7 \pm 18.8 \mu \mathrm{m})$ compared with larch $(57.6 \pm 15.2$

$271 \mu \mathrm{m})$. Our data appear to reveal species-specific responses to short-term water stress, with spruce

272 maintaining similar daily amplitudes up to 5-6 days following the last rain event before a

273 precipitous $40 \%$ decrease of amplitude after 9-10 days. Larch shows a more constant decline in

274 amplitude over time. Although larch has a greater decrease of its amplitude fraction (50\% after 9-10

275 days) than spruce, they do not show any sudden decreases of stem water movement. These 
276 observations lead us to infer that the monitored species have different physiological mechanisms for 277 dealing with short-term water stress. 


\section{Discussion and Conclusions}

Our high-resolution measurements collected over four years allow us to improve our physiological understanding of diurnal cycle mechanisms: transpiration and water uptake during the growing season and winter freeze-thaw. Both mechanisms are fundamentally linked with water movement and storage in the elastic stem tissues (Zweifel et al., 2001).

During the growing season, the daily cycles (Fig. 3) reflect a delicate balance between canopy water loss and soil water absorption (Wronski et al., 1985; Kozlowski et al., 1997; Devine and Harrington, 2011). We observed stem contraction generally from mid-morning until early evening when canopy water demand exceeds water absorption via the roots (Herzog et al., 1995; Kozlowski et al., 1997). Conversely, expansion of the stem, when water uptake is greater than losses to the atmosphere (Kozlowski and Winget, 1964), starts in the evening and continues to the

290 following morning. Absorption by the root system occurs more slowly than water losses from transpiration resulting in a more negative water potential within the sapwood (Herzog et al., 1998). This decreased potential initiates a transfer of water from surrounding elastic tissues (e.g., enlarging xylem cells, cambial cells, phloem, and bark parenchyma) towards the xylem resulting in a decrease

294 of stem size (Zweifel et al., 2000; Zweifel and Häsler, 2001; Sevanto et al., 2011). Beginning in the

295 evening, the water potential in the xylem increases as the stem is refilled by the uptake of soil

296 water. These changes in stem size, quantified by the amplitude in our study, are signals integrating

297 physiological responses to environmental variability. The timing and magnitude of daily stem

298 contractions provide insights as to the relative changes in transpiration and/or soil water status over 299 time.

300 In comparison to the growing season, during winter, a phase shift in the daily cycles is

301 observed with maximum stem size in the late afternoon (Fig. 5). In our study, the similarity of stem 302 size changes between deciduous larch and evergreen spruce (not shown) demonstrates that 
303 transpiration is no longer the primary driver of winter circadian stem cycles. These observations

304 agree with Sevanto et al. (2006), who studied stem diameter variation of Scots pine in southern

305 Finland, and concluded that although photosynthesis was observed during the winter, air

306 temperature is the dominant factor determining stem size fluctuations. The winter cycles have been

307 attributed to osmotic water movement due to temperature changes around the freezing point of the

308 sap (Zweifel and Hasler, 2000; Mayr et al., 2006). When temperatures sink below approximately -

$3095^{\circ} \mathrm{C}$, extra-cellular water begins to freeze inducing the osmotic withdrawal of intra-cellular water

310 and thus cell and ultimately stem shrinkage (Zweifel et al., 2000; Pearce, 2001; Strimbeck et al.,

311 2008). When temperatures rise sufficiently during the day the process is reversed and water begins

312 to flow back into the cells, leading to stem expansion and a daily maximum (Turcotte et al., 2009).

313 The daily amplitudes that result from these freeze-thaw processes are much smaller than the

314 transpiration driven signals observed during the growing season. However, the same physiological

315 process can result in sudden large decreases in stem size, as exemplified in Figure 5, which

316 correspond to events of sudden, large temperature decreases below the freezing point of sap. We

317 hypothesize that a sudden temperature decrease results in larger stem size reductions because a

318 greater volume of water is frozen. Additional evidence for temperature as the driver of these winter

319 freeze-thaw cycles from our study is the relative absence of freeze-thaw events at N08, the warmest

320 site on the altitudinal transect. A comparison of the air temperatures between N08 and all other sites

321 reveal a difference of $\sim 5^{\circ} \mathrm{C}$ during the winter, large enough that temperatures rarely descend below

322 the sap-freezing point. Additionally, the mean daily cycle at N08 does not show a clear phase shift

323 during the winter months concurrent with the other seven sites. We conclude that there is a distinct

324 winter diurnal cycle and that is driven by ambient temperature changes. Although not occurring

325 during the growing season, the diurnal cycles captured by dendrometers represent an opportunity to

326 further investigate the impact of freezing and thawing on tree growth. 
The magnitude and duration of annual cycles from our sites are within the range of those

330 described from other gymnosperms at both alpine and boreal locations (Tardif et al., 2001; Zweifel

331 and Häsler, 2001; Biondi et al., 2005; Duchesne and Houle, 2011). Our observation of phase shifts

332 of the diurnal cycle when comparing cycles in both winter and summer broadly agrees with

333 Turcotte et al. (2009), who divide the year into three periods: winter shrinkage, spring rehydration

334 and summer transpiration based on the timing of daily stem contraction and expansion as well as

335 the temperature during these phases. However, we did not consistently identify a true spring

336 rehydration period, defined as the period when plant tissues rehydrate in preparation for cell

337 division (Turcotte et al., 2011). Instead, our observation of low diurnal amplitudes in March is a

338 function of the shift between winter and summer and the destructive interference between their

339 respective waveforms, which are either temperature driven or a function of active water movement

340 in the stem. This conclusion is supported by the amplitude minimum observed in November at the

341 end of the growing season and start of winter dominated cycles.

342 Our study is unique in its ability to assess how seasonal transitions take place across an

343 altitudinal transect, providing a natural ecological experiment with a steep environmental gradient

344 driven by temperature (Körner, 2007). We observe that summer diurnal cycles occur earlier at sites

345 located at lower elevations and similarly, the transition to winter cycles takes place later in the

346 autumn. Based upon our altitudinal gradient, we propose that the primary factor driving transitions

347 between cycles is temperature. Temperature thresholds for the beginning of xylogenesis and more

348 general vegetative biological activity are suggested to occur when daily temperatures exceed $4-6^{\circ} \mathrm{C}$

349 (Körner, 2006; Rossi et al., 2008). Sites located at higher elevations (1900 and 2200 m a.s.1.)

350 require more time to surpass these temperatures, inferring that summer diurnal cycles of trees at

351 these locations would start later than trees at 1300 or $800 \mathrm{~m}$ a.s.l. This conclusion is supported by

352 the work of Moser et al. (2010), who investigated the timing of xylem formation in Larix decidua 
353 across this altitudinal gradient during the 2007 growing season. They found that needle budburst

354 and each phase of xylogenesis started later at higher elevations (2.9 - 3.7 days $/ 100 \mathrm{~m})$. These delays

355 were associated with temperature declines as altitude increased and a lengthening of the overall

356 growing season of $\sim 7$ days $/{ }^{\circ} \mathrm{C}$, suggesting that temperature is the primary control for growth onset.

357 Investigations of the relation between air temperature and daily cycle amplitude at our sites

358 showed clear increases of amplitude with increased temperature, which we relate to increased

359 canopy transpiration rates and water demands. Comparison of the diurnal cycles and regression

360 equations for the monitored species (Picea abies and Larix decidua) reveals similar timing for the

361 beginning of stem water use, but greater amplitudes in spruce. This implies that during a diurnal

362 period, Picea abies exploit their internal stem water reserves more quickly than Larix decidua. One

363 possible explanation for this pattern is that European larch have a greater conductivity area and

364 therefore a greater capacity for water reserves compared to Norway spruce (Schulze et al., 1985;

365 Gower and Richards, 1990; Bryukhanova and Fonti, in review). An alternative and perhaps more

366 simple hypothesis relates to the difference in the root systems between the two species. As a pioneer

367 species, larch have deeper root systems than spruce and this may allow larch to access additional

368 soil water resources and limit the use of internal reserves (Gower and Richards, 1990; Tjoelker et

369 al., 2007). However, with projected warming, we expect larch will experience greater stem

370 contraction with increasing temperatures and at the warmest sites, perhaps eventually exceed the

371 daily amplitude of spruce. These results are in agreement with recent research from lower-elevation

372 sites in the Swiss Alps that has found European larch growth had the most-negative response to

373 soil-water limitations (Eilmann and Rigling, 2012). These high rates of water-loss on already dry

374 sites could severely limit growth and may even lead to tree death.

375

376

4.3. Climatic drivers 
In addition to examining the spatial and temporal aspects of the diurnal stem cycle, we also

378 investigated the influence of different meteorological variables on circadian rhythms. Similar to our

379 findings, investigations performed with high-resolution measurements of stem size consistently find

380 responses to changes in the short-term weather conditions (Fritts and Fritts, 1955; Kozlowski and

381 Winget, 1964; Herzog et al., 1995; Devine and Harrington, 2011). However, with our methods, we

382 are also able to examine daily stem size variations on an annual scale and find that maximum

383 amplitudes of the daily cycles were found in June and July, coinciding with the highest

384 temperatures at the study sites. Additionally, intensification of the daily amplitude was found with

385 increasing daily mean air temperatures and greater amounts of sunshine. Both of these variables act

386 to increase the amount and rate of daily transpiration (Jarvis and McNaughton, 1986; McKenney

387 and Rosenberg, 1993). Increased transpiration leads to elevated water demand and due to time lags

388 with the root system, individuals must fulfill any difference in water requirements with water stored

389 in internal tissues (Herzog et al., 1998; Zweifel and Häsler, 2001). If trees do not utilize stem water,

390 it may be necessary to close stomata, which can result in carbon starvation and negative

391 consequences for tree growth (McDowell et al., 2008; Eilmann et al., 2009).

392 We see indications of these patterns when evaluating species diurnal cycle response to

393 periods without rain. Spruce experiences similar stem cycle amplitudes for approximately six days

394 before undergoing a large decrease of stem size oscillations. This behavior is consistent with a more

395 negative xylem water potential and stomatal closure to prevent large water losses when soil reserves

396 are incapable of fully replacing stem water. In contrast, larch experiences a slow, steady amplitude

397 decline indicative of greater water use to buffer increased demand. These results agree with

398 observations from the European Alps, which found that trees reduce their rates of transpiration

399 slowly with decreasing availability of water resources from the soil, and only show large reductions

400 in water use after specific thresholds are exceeded (Anfodillo et al., 1998; Clausnitzer et al., 2011). 
401 These observations indicate that the internal storage of water and the mobilization of these sources

402 on a daily basis are essential to tree productivity.

403 Our data also indicate that days with more precipitation were shown to have smaller and

404 delayed stem contractions. Precipitation events lead to an increase in available soil water, but there

405 is also evidence that rain intercepted by needles and branches can be directly absorbed and used for

406 transpiration demands from the canopy (Katz et al., 1989). However, the delay of stem contraction

407 observed on rainy days may also suggest that instead of changing water sources, the internal

408 reserves of the tree are still utilized, but are refilled nearly at depletion rate (Zweifel and Häsler,

409 2001; Steppe et al., 2006; Deslauriers et al., 2007). Regardless of the path, availability of water

410 from alternative sources reduces demand on internal water reservoirs. In addition, our weather

411 index revealed that the amount of sunshine moderated the influence of precipitation on the daily

412 stem amplitude. Increased radiation results in greater transpiration rates, leading to increased stem

413 water mobilization and thus greater stem contraction (increased amplitude). These conditions

414 appear to counteract any reduction of stem contraction based on the presence of precipitation.

415 However, during cloudy conditions and presumably decreased transpiration rates, increased water

416 availability from precipitation has a clear offset on the amount of stem contraction.

417 The plant water system is a continuum between the atmosphere, needles, stems and the soil.

418 Therefore, soil water availability may play a role in modulating the diurnal stem cycle. Kozlowski

419 and Winget (1964) proposed that diurnal stem shrinkage is primarily driven by the depletion of soil

420 water resources. This notion is not supported by our data. Although available soil water certainly

421 plays a role in the dynamics of tree water movement (and specifically short-term water stress), the

422 seasonal course of soil water at our sites decreases over time, from a maximum in spring to a

423 minimum in the fall. These trends do not coincide with the greatest amplitudes at our sites in June

424 and July. A comparison among sites is also unsupportive of the proposal of Kozlowski and Winget

425 (1964). While similar soil water availability exists across the transect (Laubscher, 2009), 
426 temperatures show a definite decrease from highest to lowest elevations, again suggesting reduced

427 stem contraction with increasing altitude is more closely linked to temperatures.

\subsection{Implications and Opportunities}

As dendrometers are broadly regarded to record tree radial growth, many long-term

431 monitoring programs sites rely upon dendrometer measurements (Jolly et al., 2005). However, it is

432 essential to understand how processes unrelated to growth may bias these estimates. Failing to take

433 into account the variability contained within the annual cycle and intra-seasonal variation in

434 weather and tree water status when deciding upon measurement times and intervals can lead to over

435 or under-estimates of growth. Such biases would have important implications on forest models,

436 land-use management, and carbon accounting schemes.

437 Dendrometers have also been increasingly used to calculate the growth response to climatic

438 variables. The most common approach for analysis of continuous dendrometer data is the stem-

439 cycle method (Downes et al., 1999; Deslauriers et al., 2003). This method splits the diurnal cycle

440 into phases of expansion, contraction and stem radius increment (SRI) on the basis of calendar days.

441 Once these have been calculated, each phase is commonly correlated with meteorological variables

442 (Deslauriers et al., 2003, 2007; Bräuning et al., 2009; Duchesne and Houle, 2011). Most studies

443 consider the cumulative SRI to be analogous to radial growth and conclude that water based-

444 measures, such as relative humidity and precipitation are the most important factors influencing

445 growth (Oberhuber and Gruber, 2010; Krepkowski et al., 2011; Volland-Voigt et al., 2011). Our set

446 of methods removes the seasonal growth trend from the dendrometer data, but still reveals a clear

447 increase of stem size on days with precipitation. In the stem-cycle method days with precipitation

448 would be over-represented as days with a positive SRI, resulting in a greater overall contribution to

449 the cumulative SRI. We suggest that this results in artificially inflated importance of moisture

450 related meteorological variables (e.g. precipitation, VPD) during calculation of statistical relations. 
451 Although we acknowledge that turgor is required for cell growth (Verbelen and Vissenberg, 2007),

452 there is no indication that greater amounts of growth take place on days with precipitation, as trees

453 always attempt to maintain turgor through self-regulation of internal movement of water (Kroeger

454 et al., 2011). Our analyses suggest that a clear understanding of possible biases and sources of

455 statistical error are essential to working with dendrometers. Our data indicate that factors such as

456 temperature and radiation play a greater role in fine-scale stem radius dynamics and overall tree

457 growth (as calculated from dendrometer records) than widely acknowledged.

458 Intra-annual dendrometer measurements are primarily composed of two different signals,

459 water movement within the stem and growth (Herzog et al., 1995). The analyses presented herein

460 have provided a valuable step towards improving our understanding of the factors that influence

461 short-term changes in stem radius and have revealed possible biases in attributing the climatic

462 drivers of radial growth. These novel methods also contributes to the assessment of the relative

463 amounts of transpiration (and photosynthetic activity) between individuals, over time and as a

464 function of climate. Additional investigations linking observations of xylem development to

465 dendrometer records will contribute to quantifying how well irreversible radial growth is also

466 captured. This study has clearly shown strong climatic controls on reversible stem size fluctuations.

\section{Acknowledgements}

469 This work was funded by a Swiss National Science Foundation project (no. 121859) and

470 NCCR Climate (DE-TREE). We thank the WSL Dendro Sciences team for many fruitful

471 discussions, as well as Christian Ginzler for his expertize with GIS, and the residents of Ferden and

472 Kippel, especially Fabian and Ursi Ambord and the local foresters Hans Henzen and Konrad Egger

473 for their support. 


\section{Figure Captions:}

475 Figure 1. Study location. (a) Regional map showing the Lötschental (shaded red polygon) and the

476 location of the five MeteoSwiss meteorological stations (red squares) of Evolene-Villa (EVO),

477 Crans-Montana (MVE), Ulrichen (ULR), Visp (VIS) and Zermatt (ZER). (b) Digital elevation

478 model (DEM) of the Lötschental centered around the village of Ferden showing the sampling sites

479 (blue circles); the $800 \mathrm{~m}$ a.s.l. site is located just outside the valley is in 1a (blue circle). (c)

480 Schematic diagram of the transect showing site elevations, codes and sampled species.

481

482 Figure 2. Comparison of mean daily average temperatures (a), and monthly sums of precipitation

483 (b) for the monitoring years 2007-2010 (blue) and the 1987-2006 average (red). The grey shading 484 in (a) indicates the mean minimum and maximum temperatures averaged over the 1987-2006

485 period. Data were calculated as an average from a network of five MeteoSwiss weather stations in 486 the region.

488 Figure 3. A schematic of the diurnal cycle of stem radius (DR). The local maximum $\left(\mathrm{R}_{\max }\right)$ and 489 minimum $\left(R_{\min }\right)$ stem radius, and the daily amplitude $(\Delta R)$, which is difference between the $R_{\max }$ 490 and $\mathrm{R}_{\min }$ are indicated. The $\mathrm{T}_{\max }$ and $\mathrm{T}_{\min }$ indicate the respective times when the local maximum and 491 minimum radius occur. A phase shift is represented by the grey dashed line.

493 Figure 4. Hourly DR records of: (a-b) four trees located at a single site (S16), and (c-d) site 494 averages along a $1400 \mathrm{~m}$ altitudinal gradient. The top panels show four complete growing seasons, 495 from 2007 until 2010; and the bottom panels show the same data for a two month period from June 4962010 to August 2010. 
498 Figure 5. Hourly stem contraction and air temperatures (shaded red below $-5^{\circ} \mathrm{C}$ ) from each site

499 along the altitudinal gradient (increasing elevation from left to right). Data are from December 2009

500 and represents site averages of all tree and dendrometer types.

501

502

503 Figure 6. Relations between mean monthly diurnal cycle amplitude and mean monthly air

504 temperature, grouped by species. Regression lines were calculated based on a linear mixed-effects

505 model and were calculated for each species individually. Data are limited to days with no

506 precipitation during the growing season (April-October) over the four growing seasons (2007-

507 2010).

508

509 Figure 7. Monthly mean circadian cycle during the growing season (April - October) for primary

510 meteorological drivers: (a) the daily amount of rain received; (b) the mean daily temperatures; (c)

511 the amount of sunshine received during a given day adjusted for number of daylight hours; and (d)

512 according to overall weather conditions. Data consist of all point dendrometers averaged across all

513 species and sites and considers four growing seasons (2007-2010). All weather drivers were

514 calculated from the network of five meteorological stations (see Fig. 1).

515

516 Figure 8. Mean circadian cycles during the growing season (April - October) grouped by the

517 number of days since the last precipitation event. Data is divided by species (a) larch, and (b)

518 spruce. Panel (c) shows the amplitude decrease as time since rain event increases for both species. 519

520 Table 1. 
521 Descriptive statistics of the monthly mean diurnal cycles presented in Figure 5. Here all five sites

522 are combined to obtain characteristics for each month. Data are composited over four complete

523 growing seasons (2007-2010).

524

525 Table 2.

526 Descriptive statistics of the mean circadian cycle during the growing season (April - October) for

527 primary meteorological drivers as presented in Figure 7. Data consist of all point dendrometers

528 averaged across all species and sites and includes four complete growing seasons (2007-2010). 


\section{References:}

531

532

533

534

535

536

537

538

539

540

541

542

543

544

545

546

547

548

549

550

551

552

553

554

555

556

557

558

559

560

561

562

563

564

565

566

567

568

569

570

571

572

573

574

575

576

577

Anfodillo, T., Rento, S., Carraro, V., Furlanetto, L., Urbinati, C., Carrer, M., 1998. Tree water relations and climatic variations at the alpine timberline: seasonal changes of sap flux and xylem water potential in Larix decidua Miller, Picea abies (L.) Karst. and Pinus cembra L. Ann. For. Sci. 55, 14.

Bechet, S., 2010. Dendroökologische Untersuchungen zur Optimalen Wachstumzone von Lärchen und Fichten im Lötschental (Diplomarbeit).

Biondi, F., Hartsough, P., 2010. Using Automated Point Dendrometers to Analyze Tropical Treeline Stem Growth at Nevado de Colima, Mexico. Sensors 10, 5827-5844.

Biondi, F., Hartsough, P.C., Estrada, I.G., 2005. Daily weather and tree growth at the tropical treeline of North America. Arctic Antarctic and Alpine Research 37, $16-24$.

Bonan, G.B., 2008. Forests and climate change: forcings, feedbacks, and the climate benefits of forests. Science 320, 1444-1449.

Bormann, F.H., Kozlowski, T.T., 1962. Measurements of tree growth with dial gage dendrometers and vernier tree ring bands. Ecology 43, 289-294.

Bouriaud, O., Leban, J.M., Bert, D., Deleuze, C., 2005. Intra-annual variations in climate influence growth and wood density of Norway spruce. Tree Physiology 25, 651-660.

Bräuning, A., Volland-Voigt, F., Burchardt, I., Ganzhi, O., Nauss, T., Peters, T., 2009. Climatic Control of Radial Growth of Cedrela Montana in a Humid Mountain Rainforest in Southern Ecuador. Erdkunde 63, 337-345.

Byrnes, J., Stachowicz, J.J., Hultgren, K.M., Randall Hughes, A., Olyarnik, S.V., Thornber, C.S., 2006. Predator diversity strengthens trophic cascades in kelp forests by modifying herbivore behaviour. Ecology Letters 9, 61-71.

CH2011, 2011. Swiss Climate Change Scenarios CH2011. C2SM, MeteoSwiss, ETH, NCCR Climate, and OcCC, Zürich, Switzerland.

Clausnitzer, F., Köstner, B., Schwärzel, K., Bernhofer, C., 2011. Relationships between canopy transpiration, atmospheric conditions and soil water availability--Analyses of long-term sapflow measurements in an old Norway spruce forest at the Ore Mountains/Germany. Agricultural and Forest Meteorology 151, 1023-1034.

Daubenmire, R.F., 1945. An Improved Type of Precision Dendrometer. Ecology 26, pp. 97-98.

Deslauriers, A., Anfodillo, T., Rossi, S., Carraro, V., 2007. Using simple causal modeling to understand how water and temperature affect daily stem radial variation in trees. Tree Physiol. 27, 1125-1136.

Deslauriers, A., Morin, H., Urbinati, C., Carrer, M., 2003. Daily weather response of balsam fir (Abies balsamea (L.) Mill.) stem radius increment from dendrometer analysis in the boreal forests of Quebec (Canada). Trees-Structure and Function 17, 477-484.

Devine, W.D., Harrington, C.A., 2011. Factors affecting diurnal stem contraction in young Douglas-fir. Agricultural and Forest Meteorology 151, 414-419.

Downes, G., Beadle, C., Worledge, D., 1999. Daily stem growth patterns in irrigated Eucalyptus globulus and E-nitens in relation to climate. Trees-Structure and Function 14, 102-111.

Drew, D.M., Downes, G.M., 2009. The use of precision dendrometers in research on daily stem size and wood property variation: A review. Dendrochronologia 27, 159-U7.

Duchesne, L., Houle, D., 2011. Modelling day-to-day stem diameter variation and annual growth of balsam fir (Abies balsamea (L.) Mill.) from daily climate. For. Ecol. Manage. 262, 863-872.

Eilmann, B., Rigling, A., 2012. Tree-growth analyses to estimate tree species' drought tolerance. Tree Physiol.

Eilmann, B., Zweifel, R., Buchmann, N., Fonti, P., Rigling, A., 2009. Drought-induced adaptation of the xylem in Scots pine and pubescent oak. Tree Physiology 29, 1011-1020. 
Frank, D.C., Esper, J., Raible, C.C., Büntgen, U., Trouet, V., Stocker, B., Joos, F., 2010. Ensemble reconstruction constraints on the global carbon cycle sensitivity to climate. Nature 463, 527-530.

Fritts, H.C., 1976. Tree Rings and Climate. Academic Press, London.

Fritts, H.C., Fritts, E.C., 1955. A new dendrograph for recording radial changes of a tree. Forest Sci. $1,271-276$.

Gessler, A., Brandes, E., Buchmann, N., Helle, G., Rennenberg, H., Barnard, R.L., 2009. Tracing carbon and oxygen isotope signals from newly assimilated sugars in the leaves to the tree-ring archive. Plant, Cell \& Environment 32, 780-795.

Gower, S.T., Richards, J.H., 1990. Larches - Deciduous Conifers in an Evergreen World. BioScience 40, 818-826.

Gruber, A., Zimmermann, J., Wieser, G., Oberhuber, W., 2009. Effects of climate variables on intra-annual stem radial increment in Pinus cembra (L.) along the alpine treeline ecotone. Annals of Forest Science 66.

Herzog, K.M., Hasler, R., Thum, R., 1995. Diurnal Changes in the Radius of a Sub-Alpine Norway Spruce Stem - Their Relation to the Sap Flow and Their Use to Estimate Transpiration. Trees-Structure and Function 10, 94-101.

Herzog, K.M., Thum, R., Kronfuss, G., Heldstab, H.J., Hasler, R., 1998. Patterns and mechanisms of transpiration in a large subalpine Norway spruce (Picea abies (L.) Karst.). Ecological Research 13, 105-116.

Husch, B., Beers, T.W., Kershaw, J.A., 2003. Forest Mensuration. John Wiley and Sons. Hutjes, R.W.A., Kabat, P., Running, S.W., Shuttleworth, W.J., Field, C., Bass, B., da Silva Dias, M.F., Avissar, R., Becker, A., Claussen, M., Dolman, A.J., Feddes, R.A., Fosberg, M., Fukushima, Y., Gash, J.H.C., Guenni, L., Hoff, H., Jarvis, P.G., Kayane, I., Krenke, A.N., Liu, C., Meybeck, M., Nobre, C.A., Oyebande, L., Pitman, A., Pielke Sr., R.A., Raupach, M., Saugier, B., Schulze, E.D., Sellers, P.J., Tenhunen, J.D., Valentini, R., Victoria, R.L., Vörösmarty, C.J., 1998. Biospheric Aspects of the Hydrological Cycle. Journal of Hydrology 212-213, 1-21.

IPCC, 2007. Solomon, S., Qin, D., Manning, M., Chen, Z., Marquis, M., Averyt, K.B., Tignor, M., Miller, H.L., (eds.) Climate Change 2007: The Physical Science Basis. Contribution of Working Group I to the Fourth Assessment Report of the Intergovernmental Panel on Climate Change. Cambridge University Press, Cambridge, UK and New York, NY, USA.

IUSS Working Group WRB, 2006. World reference base for soil resources 2006 ( No. 103), World Soil Resources Reports. FAO, Rome.

Jarvis, P.G., McNaughton, K.G., 1986. Stomatal Control of Transpiration: Scaling Up from Leaf to Region. Adv. Ecol. Res. Volume 15, 1-49.

Jemelin, L., Hügi, T., Ledermann, H., Schläppi, E., 1985. Lötschental. Geologischer Atlas der Schweiz.

Jolly, W.M., Dobbertin, M., Zimmermann, N.E., Reichstein, M., 2005. Divergent vegetation growth responses to the 2003 heat wave in the Swiss Alps. Geophys. Res. Lett. 32, 4 PP.

Jung, M., Reichstein, M., Ciais, P., Seneviratne, S.I., Sheffield, J., Goulden, M.L., Bonan, G., Cescatti, A., Chen, J., de Jeu, R., Dolman, A.J., Eugster, W., Gerten, D., Gianelle, D., Gobron, N., Heinke, J., Kimball, J., Law, B.E., Montagnani, L., Mu, Q., Mueller, B., Oleson, K., Papale, D., Richardson, A.D., Roupsard, O., Running, S., Tomelleri, E., Viovy, N., Weber, U., Williams, C., Wood, E., Zaehle, S., Zhang, K., 2010. Recent decline in the global land evapotranspiration trend due to limited moisture supply. Nature 467, 951-954.

Katz, C., Oren, R., Schulze, E.-D., Milburn, J.A., 1989. Uptake of water and solutes through twigs of Picea abies ( L.) Karst. Trees-Struct. Funct. 3, 33-37.

Körner, C., 2006. The significance of temperature in plant life, in: Plant Growth and Climate Change. Blackwell Pub., Oxford; Ames, Iowa, pp. 48-69. 
Körner, C., 2007. The use of "altitude" in ecological research. Trends in Ecology \& Evolution 22, 569-574.

Kozlowski, T.T., Kramer, P.J., Pallardy, S.G., 1997. Physiology of woody plants. Academic Press, San Diego.

Kozlowski, T.T., Winget, C.H., 1964. Diurnal and Seasonal Variation in Radii of Tree Stems. Ecology 45, pp. 149-155.

Krepkowski, J., Bräuning, A., Gebrekirstos, A., Strobl, S., 2011. Cambial growth dynamics and climatic control of different tree life forms in tropical mountain forest in Ethiopia. TreesStruct. Funct. 25, 59-70.

Kroeger, J.H., Zerzour, R., Geitmann, A., 2011. Regulator or Driving Force? The Role of Turgor Pressure in Oscillatory Plant Cell Growth. PLoS ONE 6, e18549.

Laubscher, Y., 2009. Variations intra-saisonnières de la composition isotopique $18 \mathrm{O}$ de l'eau depuis les précipitations jusqu'à l'arbre au Lötschental (Maitrise Thèse).

Makinen, H., Nojd, P., Saranpaa, P., 2003. Seasonal changes in stem radius and production of new tracheids in Norway spruce. Tree Physiology 23, 959-968.

Mayr, S., Wieser, G., Bauer, H., 2006. Xylem temperatures during winter in conifers at the alpine timberline. Agric. For. Meteorol. 137, 81-88.

McDowell, N., Pockman, W.T., Allen, C.D., Breshears, D.D., Cobb, N., Kolb, T., Plaut, J., Sperry, J., West, A., Williams, D.G., Yepez, E.A., 2008. Mechanisms of plant survival and mortality during drought: why do some plants survive while others succumb to drought? New Phytologist 178, 719-739.

McKenney, M.S., Rosenberg, N.J., 1993. Sensitivity of some potential evapotranspiration estimation methods to climate change. Agricultural and Forest Meteorology 64, 81-110.

Moser, L., Fonti, P., Büntgen, U., Esper, J., Luterbacher, J., Franzen, J., Frank, D., 2010. Timing and duration of European larch growing season along altitudinal gradients in the Swiss Alps. Tree Physiology 30, 225 -233.

Nabeshima, E., Kubo, T., Hiura, T., 2010. Variation in tree diameter growth in response to the weather conditions and tree size in deciduous broad-leaved trees. Forest Ecology and Management 259, 1055-1066.

Oberhuber, W., Gruber, A., 2010. Climatic influences on intra-annual stem radial increment of Pinus sylvestris (L.) exposed to drought. Trees-Structure and Function 24, 887-898.

Offermann, C., Ferrio, J.P., Holst, J., Grote, R., Siegwolf, R., Kayler, Z., Gessler, A., 2011. The long way down - are carbon and oxygen isotope signals in the tree ring uncoupled from canopy physiological processes? Tree Physiology 31, $1088-1102$.

Oki, T., Kanae, S., 2006. Global Hydrological Cycles and World Water Resources. Science 313, $1068-1072$.

Pearce, R., 2001. Plant freezing and damage. Ann. Bot. 87, 417-424.

Perez, C.A., Carmona, M.R., Aravena, J.C., Farina, J.M., Armesto, J.J., 2009. Environmental controls and patterns of cumulative radial increment of evergreen tree species in montane, temperate rainforests of Chiloe Island, southern Chile. Austral Ecology 34, 259-271.

Prentice, I.C., Heimann, M., Sitch, S., 2000. The carbon balance of the terrestrial biosphere: ecosystem models and atmospheric observations. Ecological Applications 10, 1553-1573.

R Development Core Team, 2012. R: A language and environment for statistical computing. R Foundation for Statistical Computing, Vienna, Austria.

Rossi, S., Deslauriers, A., Gricar, J., Seo, J.W., Rathgeber, C.B.K., Anfodillo, T., Morin, H., Levanic, T., Oven, P., Jalkanen, R., 2008. Critical temperatures for xylogenesis in conifers of cold climates. Global Ecology and Biogeography 17, 696-707.

Schulze, E.-D., Čermák, J., Matyssek, M., Penka, M., Zimmermann, R., Vasícek, F., Gries, W., Kučera, J., 1985. Canopy transpiration and water fluxes in the xylem of the trunk of Larix 
and Picea trees: A comparison of xylem flow, porometer and cuvette measurements. Oecologia 66, 475-483.

Seneviratne, S.I., Luthi, D., Litschi, M., Schar, C., 2006. Land-atmosphere coupling and climate change in Europe. Nature 443, 205-209.

Sevanto, S., Hölttä, T., Holbrook, N.M., 2011. Effects of the hydraulic coupling between xylem and phloem on diurnal phloem diameter variation. Plant, Cell \& Environment 34, 690-703.

Sevanto, S., Suni, T., Pumpanen, J., Gronholm, T., Kolari, P., Nikinmaa, E., Hari, P., Vesala, T., 2006. Wintertime photosynthesis and water uptake in a boreal forest. Tree Physiol. 26, 749757.

Steppe, K., De Pauw, D.J.W., Lemeur, R., Vanrolleghem, P.A., 2006. A mathematical model linking tree sap flow dynamics to daily stem diameter fluctuations and radial stem growth. Tree Physiology 26, 257-273.

Strimbeck, G.R., Kjellsen, T.D., Schaberg, P.G., Murakami, P.F., 2008. Dynamics of lowtemperature acclimation in temperate and boreal conifer foliage in a mild winter climate. Tree Physiol. 28, 1365-1374.

Tardif, J., Flannigan, M.D., Bergeron, Y., 2001. An analysis of the daily radial activity of 7 boreal tree species, northwestern Quebec. Enviro. Monit. Assess. 67, 141-160.

Tjoelker, M.G., Boratynski, A., Bugala, W., 2007. Biology and Ecology of Norway Spruce. Springer.

Turcotte, A., Morin, H., Krause, C., Deslauriers, A., Thibeault-Martel, M., 2009. The timing of spring rehydration and its relation with the onset of wood formation in black spruce. Agricultural and Forest Meteorology 149, 1403-1409.

Turcotte, A., Rossi, S., Deslauriers, A., Krause, C., Morin, H., 2011. Dynamics of depletion and replenishment of water storage in stem and roots of black spruce measured by dendrometers. Front. Plant Sci. 2, 21.

Verbelen, J.P., Vissenberg, K., 2007. Cell expansion: past, present and perspectives, in: The Expanding Cell, Plant Cell Monographs. Springer, Berlin, pp. 1-6.

Volland-Voigt, F., Bräuning, A., Ganzhi, O., Peters, T., Maza, H., 2011. Radial stem variations of Tabebuia chrysantha (Bignoniaceae) in different tropical forest ecosystems of southern Ecuador. Trees-Struct. Funct. 25, 39-48.

Wronski, E.B., Holmes, J.W., Turner, N.C., 1985. Phase and amplitude relations between transpiration, water potential and stem shrinkage. Plant, Cell \& Environment 8, 613-622.

Zweifel, R., Hasler, R., 2000. Frost-induced reversible shrinkage of bark of mature subalpine conifers. Agricultural and Forest Meteorology 102, 213-222.

Zweifel, R., Häsler, R., 2001. Dynamics of water storage in mature subalpine Picea abies: temporal and spatial patterns of change in stem radius. Tree Physiology 21, 561-569.

Zweifel, R., Item, H., Hasler, R., 2000. Stem radius changes and their relation to stored water in stems of young Norway spruce trees. Trees-Structure and Function 15, 50-57.

Zweifel, R., Item, H., Hasler, R., 2001. Link between diurnal stem radius changes and tree water relations. Tree Physiology 21, 869-877. 
Figure 1

a)

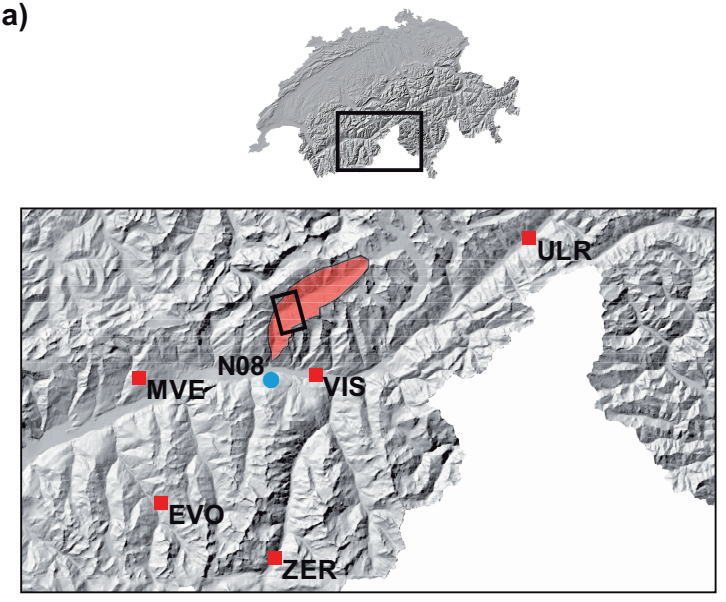

b)

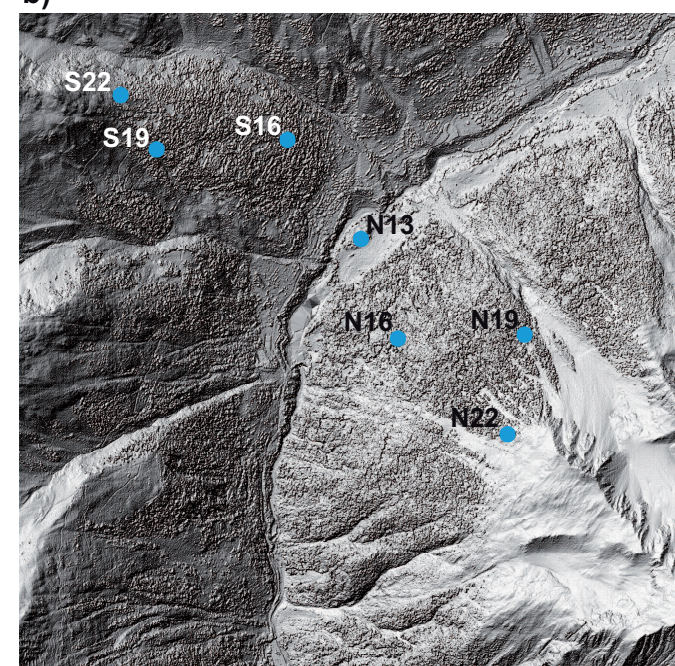

c)

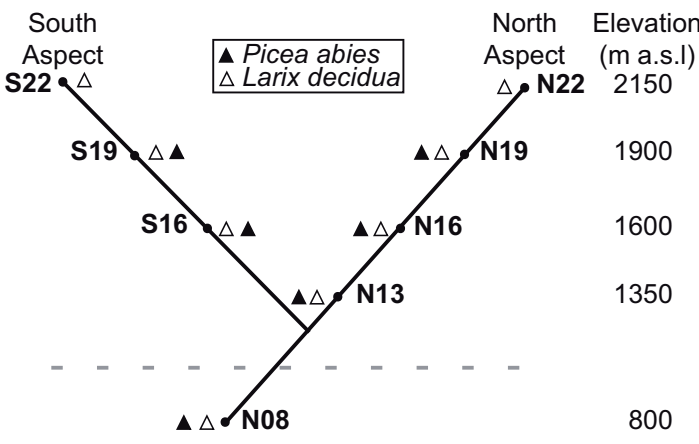




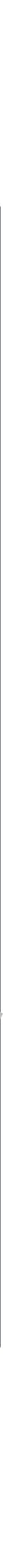

Figure 3

R

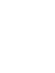

3

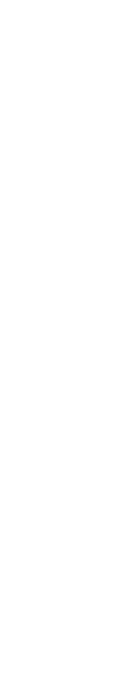

.

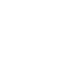

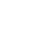

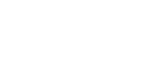
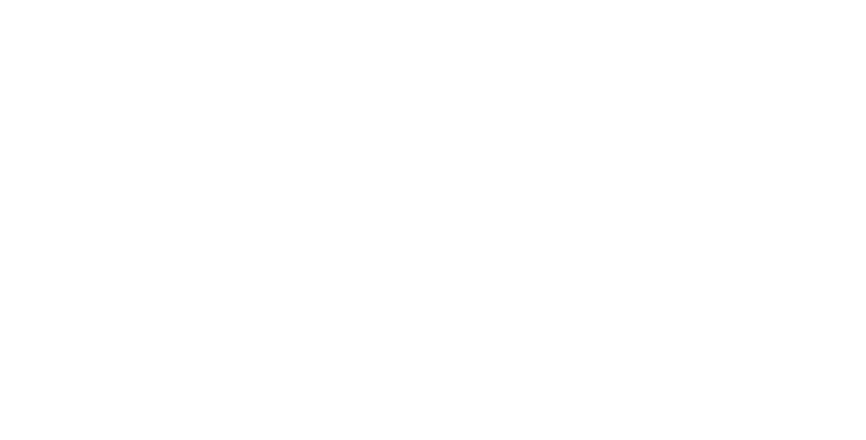
722

Figure 5

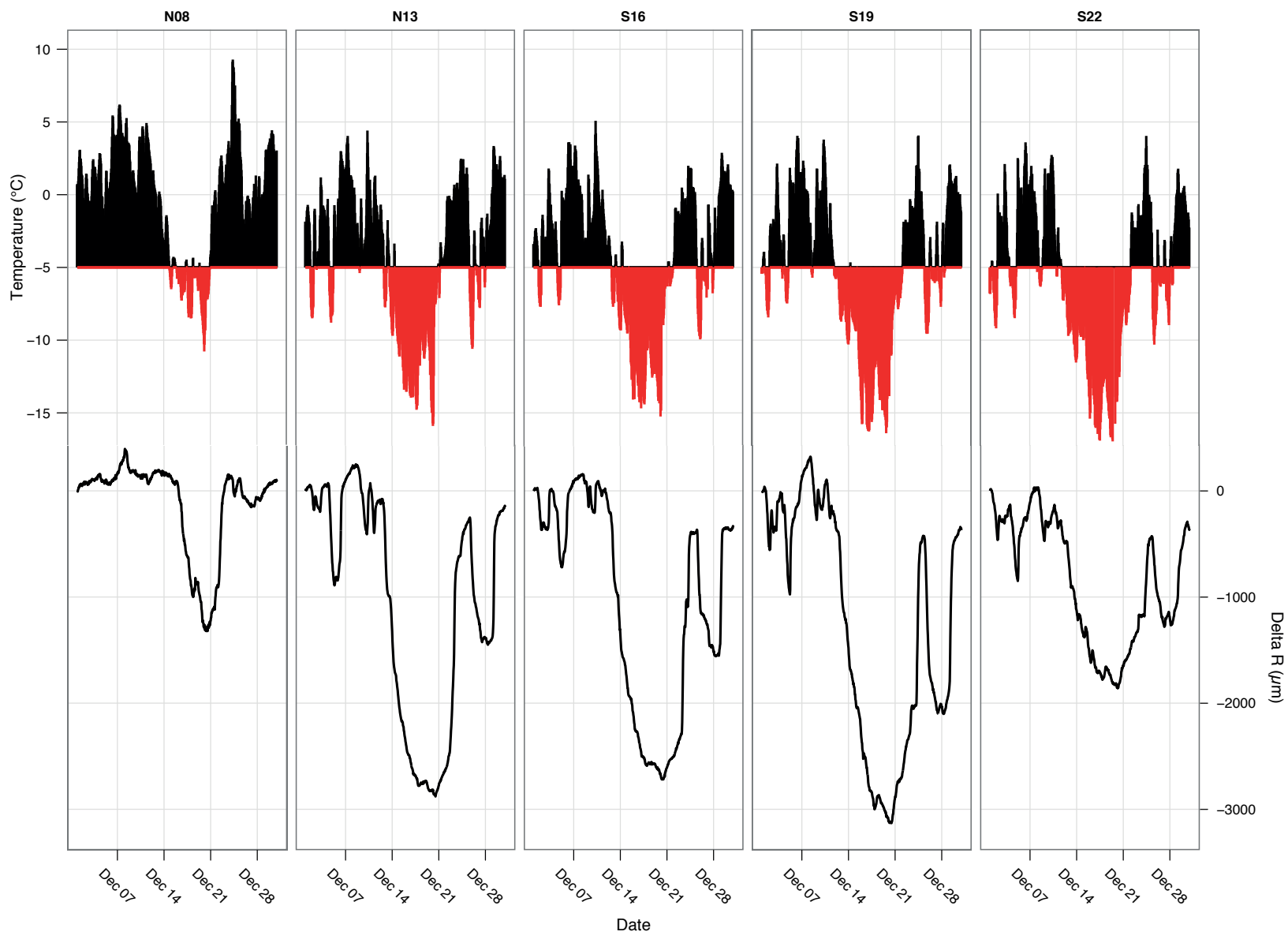


Figure 6
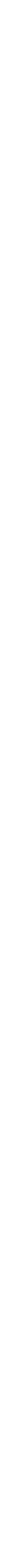
Figure 7
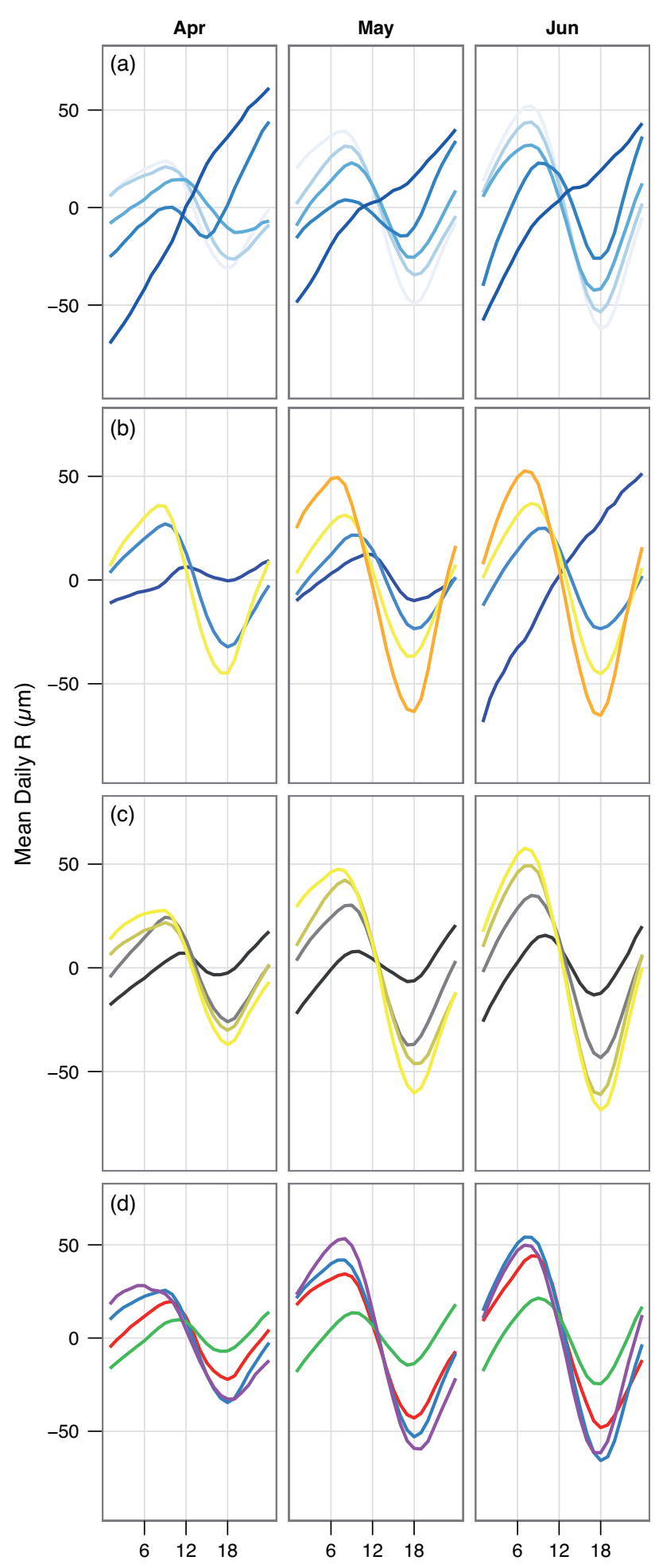
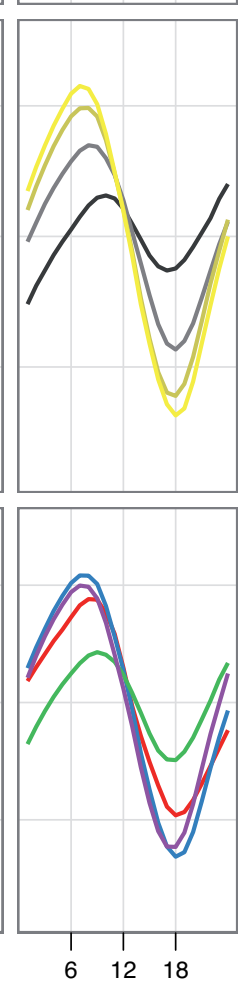
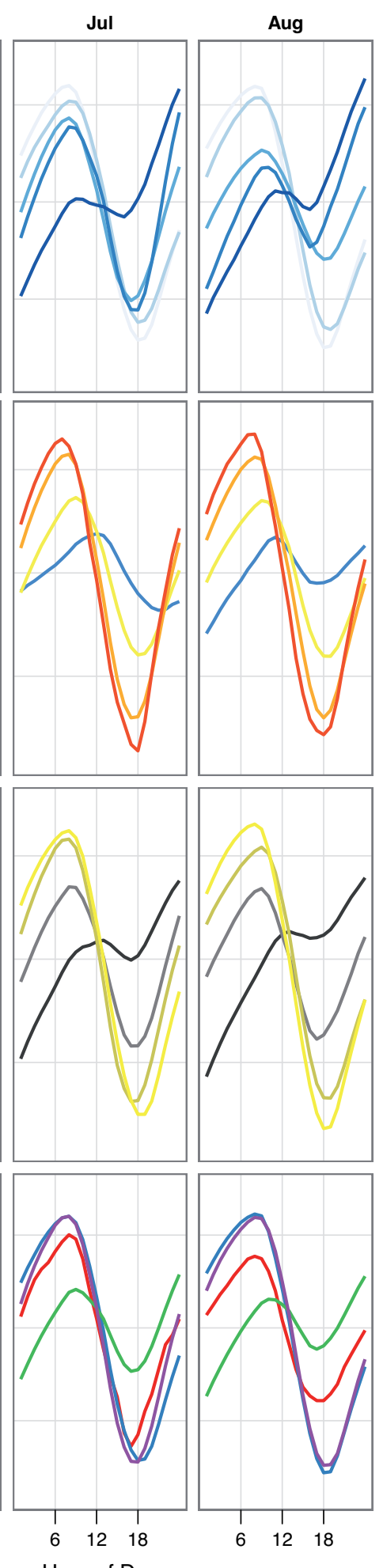
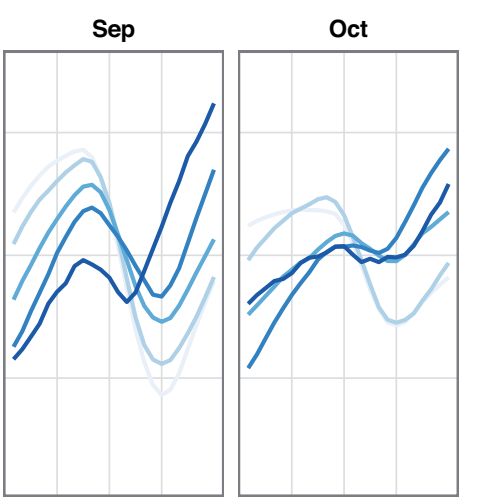

Rain (mm)
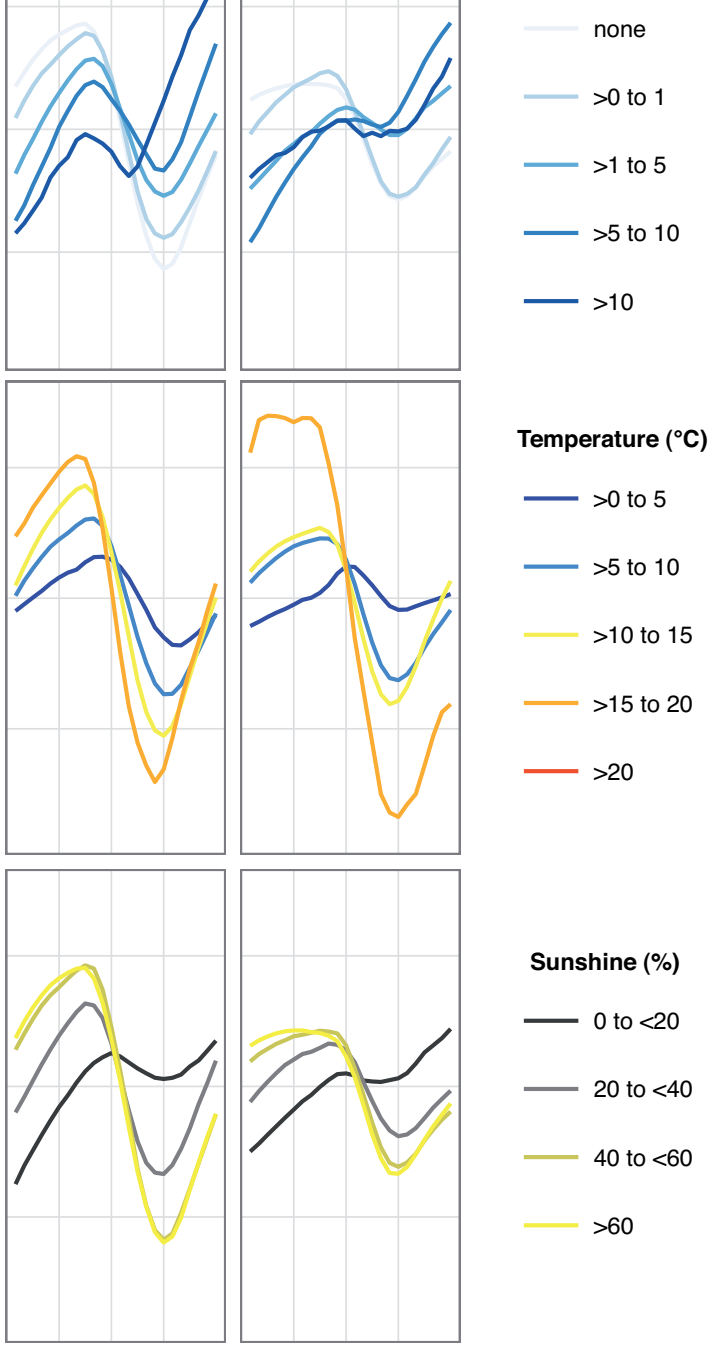

Sunshine (\%)

-0 to $<20$

-20 to $<40$

-40 to $<60$

$>60$
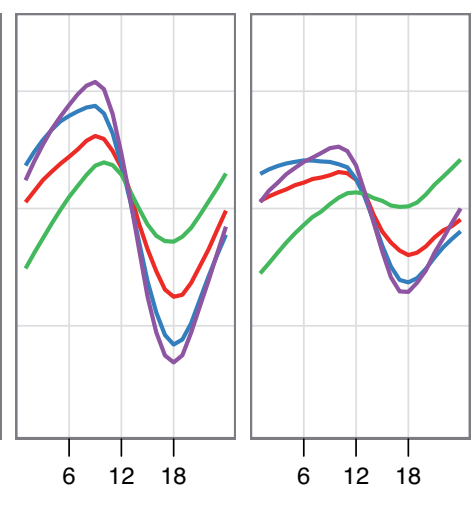

Weather

No Rain / Cloudy

- No Rain / Sunny

_ Rain / Cloudy

— Rain / Sunny 


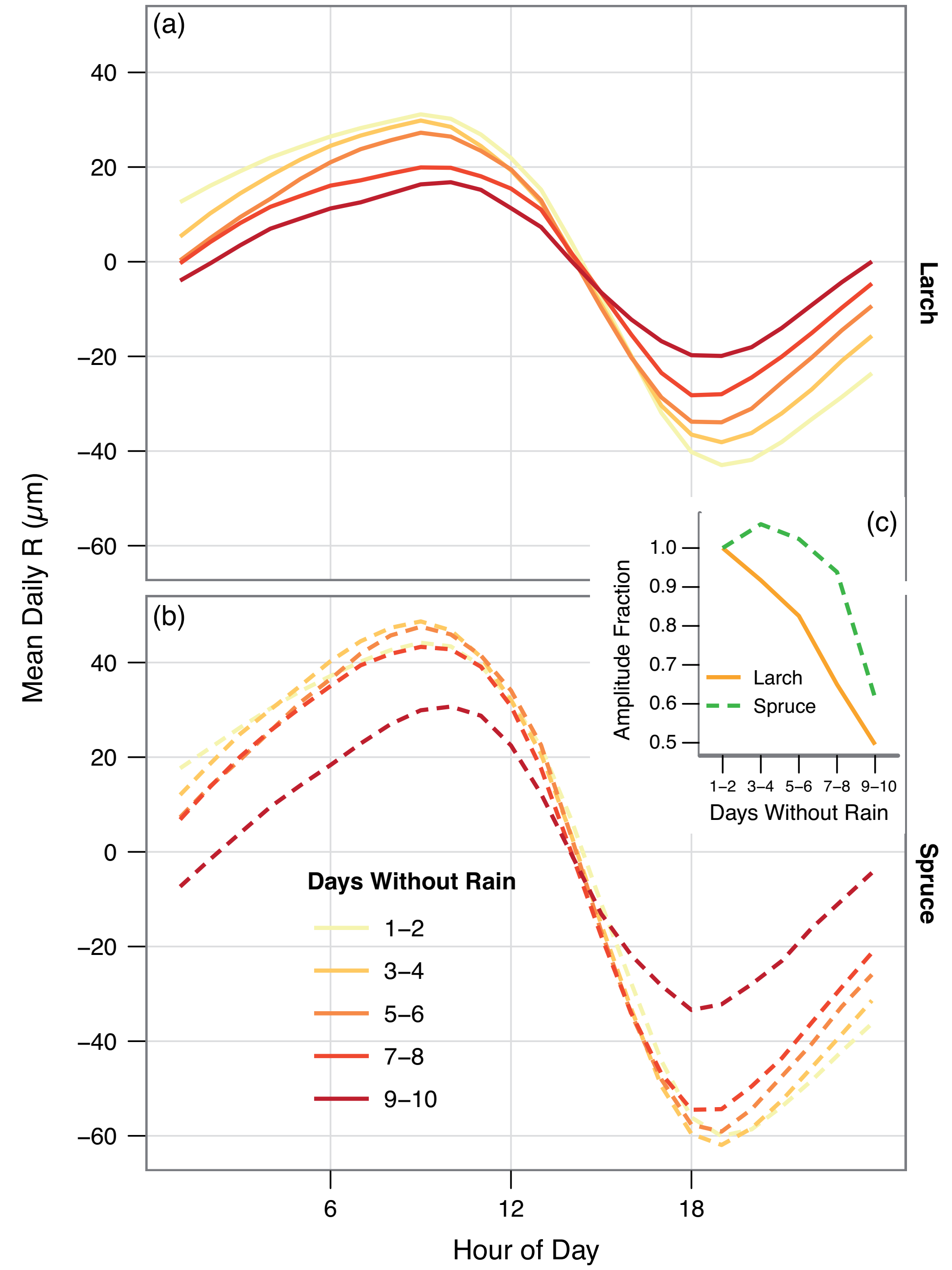

